\title{
Welcoming mobile children at school: institutional responses and new questions
}

\author{
Laure Kloetzer, et al. [full author details at the end of the article]
}

Received: 8 June 2020 / Revised: 27 January 2021 / Accepted: 28 January 2021 / Published online: 19 March 2021

(C) The Author(s) 2021

\begin{abstract}
Switzerland, like other countries in Europe, has long depended on migration and mobility for its economy. Facilitating the integration of migrant children in school, primarily through the acquisition of the local language, has therefore been a priority for policymakers. In recent years, mobility has been on the increase and mobility trajectories have become more diverse. A growing percentage of families arriving in the country have experienced repeated mobility and may not plan to settle in Switzerland for good. This paper examines institutional responses to the increasing number of mobile children in Swiss public schools, in particular, the manner in which such children are welcomed. It presents the main findings of an exploratory research project focused on children in repeated mobility, defined as having lived in multiple countries before their arrival in Switzerland, regardless of family background or legal status. Adopting a sociocultural psychological approach, the paper examines the macro-social level of cantonal educational policies regarding welcome processes, the meso-social level of local school policies, and the microsocial level of teachers' practices and interactions in classrooms that welcome mobile children. Data include documentary analysis, interviews, and observations. Our analysis shows that a deficit view of mobile children and the preoccupation with language proficiency dominate policies and practices, resulting in the diversion of mobile children into special integration classes (so called "classes d'accueil" in the French speaking region, and "Integrationsklasse" in the Swiss German-speaking region). Mobility is conceptualized by Swiss policymakers, school directors, and teachers in terms of its challenges. In particular, school directors and teachers conceptualize mobility as increasing heterogeneity of the classroom. However, the situation varies greatly according to the personal orientations of school directors and teachers' personal engagement. The paper emphasizes the ambiguous role of the integration classes: while they may impair the long-term chances of educational success by reducing academic expectations for non-native-speaking mobile children, they may also be used as "third spaces" which afford pedagogical freedom for dedicated teachers, potentially of benefit for children. The paper examines these propositions in the light of sociocultural educational literature and draws upon the case of welcoming mobile children to question a series of assumptions about the ultimate purposes of public schooling in Europe today.
\end{abstract}

Keywords Repeated mobility · Schools $\cdot$ Educational policy $\cdot$ Interactions in the classroom · Transitional spaces $\cdot$ Third spaces $\cdot$ Deficit view 


\section{Introduction}

Human mobility is a worldwide and age-old phenomenon, yet it has been increasing steadily since the 2000s (UN Department of Economic and Social Affairs 2019). The UN estimated the total number of international migrants at 272 million in 2019 , corresponding to $3.5 \%$ of the total human population. In Switzerland, 38\% of the population over 15 is a migrant - of which $80 \%$ is born abroad (Furrer et al. 2020) ${ }^{1}$. If most of these persons come from Europe, however, two types of mobility have acquired increased visibility over the past ten years, in Switzerland as in the rest of the world. Firstly, since the so-called "refugee crises" of 2015-2016 (Piguet 2018), the question of refugees has become very visible. 2.5 million asylum seekers fleeing war and violence, especially in Syria, Iraq, and Afghanistan arrived in Europe in 2015-2016 $0,25 \%$ of Europe's population- (Piguet 2019). These families often migrate for the sake of protecting their children, in search of a better life which, often, includes a safe education. Although there is a relatively modest number of refugees in Switzerland, their specific trajectories - often through repeated mobility, short or longer stays in various camps and villages, with little or disrupted formal education, and whose families of origin may have had highly contrasting socio-educational profiles - raise specific challenges for Swiss schools (Sanchez-Mazas et al. 2020). The second type of mobility that has acquired increased visibility in the world and in Switzerland is that of people or families engaging in repeated relocation as a function of the person's or family's employment or profession - the so-called expatriates, highly-skilled migrants, or cosmopolitans (Adams 2016; Caligiuri et al. 1998; Langinier and Gyger Gaspoz 2015; Ley 2004; Nedelcu 2012). Here as well, most of these families have high expectations regarding the education of their children, and in many places in the world, send them to international or private schools; in Switzerland, a large majority send them to the public school (Levitan 2018).

However, migrant, refugee, and highly skilled migrants are both administrative and common-sense categories which carry complex and potentially reifying normative values. Consequently, following the recent mobility turn in migration literature (Cresswell 2006; Dahinden 2009, 2016), we will use the term "mobility" to include all kind of geographical mobilities, including children with different administrative statuses. More specifically, we propose to use the expression of families or children in "repeated mobility" (Belin 2018; Cangià and Zittoun 2018; Levitan 2019; Zittoun and Levitan 2019) to designate the fact that they have experienced over a longer period recurrent international geographical mobility, without limiting to particular sociological or political categories the significance of this repeated mobility on their lives. Consequently, here, the expression "children in repeated mobility" may include refugee children as well as those of highly skilled families. As we will see, the term "repeated mobility" also offers a heuristic advantage, as teachers and schools may not know the specific migratory status of the children they welcome. In addition, it may also emphasize the experiential similarities for people, regardless of their political or administrative status.

In Switzerland, there is a long tradition of welcoming children with a migratory experience; the educational system is in effect conceived as tool for integration for children whose family intend to remain in Switzerland (Centlivres 1990; Cesari-Lusso 2001; Di Donato et al. 2020). In the current socioeconomic context, children with an experience of mobility or of repeated mobility, regardless of their migratory administrative status (i.e., refugee, highly skilled, etc.),

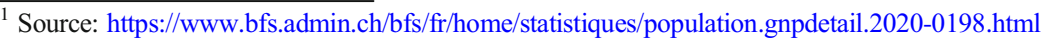


tend to go to public schools in Switzerland. Only, their families do not always stay in Switzerland; almost half of mobile people coming to Switzerland with a work permit are also likely to leave the country within 5 years (Steiner and Wanner 2019a). In other words, trajectories of mobility tend to become more fluid than they used to: even children considered as traditional "migrants" may start to repeat their mobility, and a growing number of children have already an experience of repeated mobility. Our main interrogation is therefore, does the educational system takes in account such new mobility, and if so, how? How are mobile children welcomed by Swiss public schools? How has the Swiss school system adjusted to the multiple expectations of repeatedly mobile families? Has it taken adequate account of their educational needs and projects?

In this paper, we will start by showing that policies and practices for welcoming mobile children lack consistency; they are based on a model of long-time settlement, and on an implicit deficit model. On the basis of our fieldwork, we will then suggest that, at present, it is mainly individual teachers who find some margin of freedom in educational arrangements and, on their own initiative, develop innovative didactic strategies to support the needs of mobile children in their classrooms. Approaching such findings from a sociocultural perspective, we will give particular attention to the "third spaces" created by certain teachers and highlight the importance of developing educational strategies that valorise the specific skills and experience of these children in public schools. Finally, we hope to raise some questions and invite further research and practice.

\section{Schooling mobile children in Switzerland}

\section{An historical overview of Swiss educational research on migration}

In Switzerland, educational research has followed the evolution of migration flows (D'Amato 2010; Piguet 2005, 2007, 2012). The issue of migrant children in school became a priority during the 1980s. Although migration was an important phenomenon in earlier decades, the shift from migration based on a circular model (seasonal workers expected to return to their home country after a more or less long stay) to the model of long-term settlement, either in the case of family reunifications, or due to new forms of migration (asylum seekers, refugees), made the presence of children from mobile families more visible (Piguet 2005). At that time, the issue of schooling foreign students was framed mainly as a language issue, and "integration classes" were designed as special, separate classes reserved for the acquisition of the local language(s) of schooling (in Switzerland, German, French, or Italian depending of the region). Subsequent literature reveals four key debates over these integration classes.

Firstly, discussions took place about the "sheltered" nature of these classes. Some authors showed that these not only separate children from their peers, but also bring teachers to lower their expectations towards these students, and possibly of students' themselves. Thus, integration classes actually limited the educational outcomes and opportunities of foreign students over the long-term (Doudin and Ramel 2009; Perregaux 2009; Shapiro and Ehtesham-Cating 2019). Recently, Sanchez-Mazas and colleagues criticized "the indiscriminate relegation" of such children "into special structures, as a result either of stereotyping or of teachers' feeling of helplessness - which are often intertwined" (Sanchez-Mazas et al. 2020, p. 6). In contrast, other authors underline that these classes offer protected spaces in which newcomers could develop useful skills for their further school integration (Nicolet et al. 1997; Perregaux 2009). 
Secondly, research has highlighted inequality in educational access, provision, and attainment with respect to foreign students. It has been repeatedly shown that social class plays a crucial role in the academic performance of migrant children (Cassée et al. 1989; Consortium PISA.ch 2010; Coradi Vellacott and Wolter 2005; Gomensoro and Bolzman 2015; Hutmacher 1995; Kronig 2003; Kronig et al. 2000; Meyer 2015; Rosenberg et al. 2003), and even in language acquisition (Bell and Gurny 1989; Othenin-Girard 1995; Py 1995). Authors have thus asked whether children with a migration experience in Geneva or Zurich suffered more from their working-class social origin or from their migrant status (Becker et al. 2011; Hutmacher 1995). Other studies revealed that it is the intersectionality between migration status and social class that can have a determinative effect. On this point, national surveys highlighted that "characteristics such as being migrant and from a low socio-economic status often go together, which can have a particularly negative effect on some groups of students" (Consortium PISA.ch 2010, p. 16, our translation). However, it is interesting to note that this effect may have started to recede. In the 2018 survey in Switzerland, it was found that "migratory status has no statistically significant effect once the economic, social and cultural level, as well as the gender and language spoken at home are controlled" (Consortium PISA.ch 2019 , p. 25, our translation) - which suggests either a change in educational strategies or in the profiles of mobile children.

Thirdly, research has highlighted the negative social representations of children with an experience of mobility held by the school system itself. Schools appear to construct a deficitbased and homogenous image of these children, perceiving them as encountering school difficulties due to their "cultural difference" rather than their socioeconomic status-which also shows a lack of understanding of the diversity of mobility trajectories (Perregaux 2009). The school system itself may contribute to school inequities. A recurrent observation over the last 30 years is that migrant children are more systematically oriented towards both "special education classes" (i.e., classes for children with learning difficulties, although the efficiency of such structures can be discussed) (Perregaux 2009; Schuh 1989), and towards school tracks with low professional expectations (Cassée et al. 1989; Coradi Vellacott and Wolter 2005; Poglia 1989; Wicht and Bühlmann 2003). Children moving to Switzerland from specific countries (i.e., Portugal, former Yugoslavia, Turkey) have been particularly affected by these tendencies (Becker et al. 2011; Gomensoro and Bolzman 2015; Müller 2001; Office Fédéral de la Statistique 2008; Schnell and Fibbi 2016).

Finally, Switzerland being a federal state composed of 26 cantons which are each in charge of their own educational policy, recent studies have highlighted inequalities among cantons due to the specificities of their respective schooling system and more particularly the role of the most segregating cantonal systems in producing inequalities between migrant and national children (Felouzis et al. 2016; Felouzis and Charmillot 2013, 2017). Due to cantonal variations in educational policy and provision for migrant children, educational opportunities afforded to migrant children are affected by the lottery of geographic settlement.

\section{Children in repeated mobility in public Swiss schools}

The Swiss current policy encourages the immigration of highly skilled professionals, who can enter the country if they have already a work contract. De facto, this attracts a population that has often already moved internationally and that tends to leave the country again (Steiner and Wanner 2019a). Even though there is a longstanding tendency for migrant or mobile persons 
to move away from Switzerland in the shorter or longer term ${ }^{2}$, there is an increasing number of families moving to Switzerland as part of a trajectory of repeated mobility. Typically, one would expect such families to send their children to international schools (Adams and Fleer 2016; Gyger Gaspoz 2013; Pearce 2013). Surprisingly, the migration-mobility survey conducted in Switzerland in 2015 suggested that $75 \%$ of families with an experience of repeated mobility $^{3}$ send their children to public schools (Levitan 2018). This could be explained by the high cost of living in Switzerland and the reduction of welcome packages for international professionals, as well as by many families' wishes to offer their children a "local" experience. The situation of these children and their families, who are likely to leave within five years (Steiner and Wanner 2019b), raises differentiated needs for linguistic and social integration. Such children may have known various educational systems, speak multiple languages and intend to pursue their educational and professional tracks in other countries. Simultaneously, their parents often have a rather high socio-educative background and at times develop nontypical family-school relations, for instance when fathers are the accompanying spouses and take care of children (Cangià 2017, 2018; Levitan 2019).

On the other hand, Switzerland accepts a limited number of asylum seekers; since March 1st, 2019 ${ }^{4}$, these children are not schooled with others in local schools under the responsibility of the canton, but within "federal welcome centres" (i.e., refugee camps) in which the family's asylum request must be decided within 140 days of their arrival. Under the responsibility of the federal authorities, children of asylum seekers-whether allophone or not - receive minimal education in these temporary and enclosed spaces. If the parents' request for asylum is denied, the family is required to leave the country; if it is granted, the children are then permitted to join local schools. This new schooling policy, which accompanies the revision of the law on the asylum-seeking process, has been strongly criticized by NGOs and volunteer organizations involved in the protection of migrants and children ${ }^{5}$, based on the limited number of school hours offered in these federal camps, as well as the limited interactions with the local population and restricted possibilities for local integration. In response, some localities such as Zurich have modified the federal policy to enable children living in the federal refugee camp to attend local schools with children of their age.

The presence of highly mobile children, whether from highly skilled mobile families or from refugee families, thus exposes Swiss schools to new challenges. Firstly, both types of mobile children have often had multiple and unequal experiences of schooling and have developed various sets of skills during their trajectories. Secondly, many of these children's families do not plan on long-term settlement in Switzerland. These children are quite likely to move again and join further schools or educational settings in other countries. These realities thus contradict the basic assumption of stability within a nation-state that drives the curriculum and pedagogy of public schools. We thus raise the question of how schools, in countries such

\footnotetext{
${ }^{2}$ For instance, "Among the main immigration groups in 1998, 63\% of German and French, 55\% of Italian and $36 \%$ of Portuguese migrants left Switzerland within nineteen years after their arrival." (Migration-Mobility Indicators. Neuchâtel: nccr-on the move, 2019)

${ }^{3}$ Within the nccr survey conducted in Switzerland in 2016 (N=5973), "mobile families" were defined as people who arrived in Switzerland for professional reasons, with a partner and at least one child born abroad, having already lived in another country between their country of birth and Switzerland (Steiner and Wanner 2019b).

${ }^{4}$ See, for example: https://www.osar.ch/revision-de-la-loi-sur-lasile.html.

${ }^{5} \mathrm{See}$, for example, the website of Human Rights https://www.humanrights.ch/fr/droits-humains-suisse/ interieure/politique-sociale/education/ecole-integration-enfants-etrangers, and the press release of the association Droit de rester Neuchâtel, https://asile.ch/2019/02/07/droit-de-rester-neuchatel-scolarisation-desenfants-refugies-au-centre-federal-de-perreux/.
} 
as Switzerland, welcome children that have the experience and expectation of repeated mobility. More specifically, little is known about the demands on teachers and the strategies they develop, if any, to welcome children in repeated mobility who arrive with distinct educational trajectories.

In this paper, based on an exploratory research led in Switzerland ${ }^{6}$, we explore how welcoming children with an experience of repeated mobility is conceptualized, articulated, and practiced in public schools.

\section{Adopting a sociocultural perspective on educational settings}

Before going further, we need to specify the theoretical perspective we have taken on learning and teaching. We adopt a sociocultural perspective, which examines the interdependence between the person and her social and cultural environment through the person's interactions with others and artefacts in different settings (e.g., Cole 1996; Valsiner 2007). Such an approach invites us to apprehend the sociocultural world in its complexity and evolution, how actual interactions unfold within it, as well as people's unique developmental trajectories. With its emphasis on processes, a sociocultural perspective considers that these various aspects mutually constrain and enable each other. It also brings us to consider both people's activities, and the sense and meaning that these have for various actors (Valsiner 2014; Zittoun et al. 2013).

Sociocultural psychology also invites us to go beyond a naïve understanding of "culture": culture cannot be reduced to either national belonging or to social class (Dahinden 2012; Goodnow 2004; Valsiner 2014). Culture represents the totality of human productions over history; yet depending upon their location in time and place, children grow up in a variety of cultural systems, which may be more or less organized and institutionalized, in such a way that any person is actually socialized into a wide range of cultural subsystems (Cole 1996; Valsiner 2014; Zittoun et al. 2013). Understood in these terms, the concept of culture cannot be used to explain the difficulties of "migrant" children (a political category) by their "cultural" difference. Consequently, such a view makes us approach with caution didactic and educational practices that consider themselves to be "multicultural" or engaged in the respect of "cultural diversity" but which promote, in fact, a reified vision of culture.

Applied to education, a sociocultural approach invites us to explore the macrosocial conditions whereby the context sets the conditions for education, the mesosocial nature of actual educational settings, and the microsocial unfolding of interactions within them (De Abreu 2000; Hedegaard 2003; Valsiner 2014). Rather than seeing these levels as simply embedded in one another, a sociocultural approach is attentive to dialogical dynamics by which various sociocultural norms and voices circulate, become negotiated, appropriated or resisted (Grossen 2010; Grossen et al. 2012; Marková 2003). It also considers that teachers and students are active beings, engaged in activities that are mediated by cultural tools, to which

\footnotetext{
${ }^{6}$ The exploratory project MoChiS (Mobile Children in Schools), funded for 15 months by the nccr-on-the-move grant from the Swiss National Fund, sought to examine (a) whether schools observed and/or documented an increase of repeatedly mobile children; (b) what specific challenges teachers meet when they have such children in their classes; (c) what strategies schools and/or teachers develop to handle these new realities, and what can be learned from these; and (d) how schools could be supported, whether at the level of teacher training, teaching support, communication to families, school programs, etc.
} 
they confer meaning and that can make more or less sense to them (Rochex 1998; Zittoun 2017a).

From such a perspective, it thus becomes clear that any national educational system reflects some dominant values, ideals, norms, and representations that emerge from and are constitutive of the cultural subsystems of that place and time. Indeed, every educational institution has a double project of reproducing society (and preparing children to it) and maintaining itself, while at the same time, evolving (deliberately or inadvertently) so as to adjust to or anticipate societal changes (Cabra and Zittoun 2021; Mehmeti and Zittoun 2019; Zittoun 2016).

Hence, such a theoretical frame invites us to approach the question of how Swiss public schools welcome children with a trajectory of repeated mobility in a multilevel and dynamic way. At the centre of our enquiry, we will examine the actual, daily interactions to which mobile children take part in classrooms. Yet to capture these, we first need to retrace the macrosocial environment - the historical and legal context of schools' activities. Second, given the nature of the object and the margin of freedom that each canton and each school has, we have to examine at a meso-level the institutional norms and practices which locally create the conditions, guide, enable and shape these interactions; as we will see, most schools design some form of dispositive, or setting, meant to welcome mobile children, seen as allophones. And third, we need to account for the actual nature of these activities: how they are carried out, what tools mediate them, how people engage in them, negotiate their meaning, and make sense of them. Our theoretical frame also invites us to examine echoes and resonances across these levels, how divergent meanings may create conflicts, tensions, or constraints for the actors, but also margins of freedom; and finally, how these tensions may generate critical incidents, which themselves may, under certain circumstances, trigger innovation and change (Cole and Engeström 2007; Engeström 2008; Engeström et al. 2015; Zittoun 2017a).

\section{Context and methodology of the research}

To explore the way in which mobile children are welcomed by the Swiss educational system, we conducted an exploratory qualitative study. Following our theoretical frame, we organized our data collection along three interrelated levels of analysis. We considered (1) the macrolevel of the wider education system and global context (esp. cantonal policies), (2) the mesolevel of the learning environment (school-level: policy, school architecture, local geographical and social-economic environment of the school, etc.), and (3) the micro-level of the interactions in the classroom (teachers' practices, learning tasks, classroom architecture, classroom interactions, etc.). We also adopted a case-study approach (Flyvbjerg 2011; Zittoun 2017b), with each school being a case embedded in a larger social and political context and comprised of different classrooms with teachers adapting and developing creatively their own local approach to schooling mobile children. We thus aimed at highlighting both the role of the institutional context and policies in shaping local practices, and the margin of freedom and professional engagement of teachers within these conditions.

\section{Overall data collection}

We documented classes from Cycle 2 (corresponding to children aged 8-12-that is, before orientation in different secondary school tracks), in both French and German speaking regions of Switzerland. We initially planned to study classes in two French-speaking schools, and two 
Table 1 Data collection

\begin{tabular}{|c|c|c|}
\hline & Urban setting & Peripheral setting \\
\hline $\begin{array}{c}\text { French-speaking } \\
\text { Switzerland }\end{array}$ & $\begin{array}{l}2 \text { schools Canton Neuchâtel: } \\
-2 \text { interviews with director } \\
-7 \text { interviews ( } 2 \text { with "welcome" class teacher, } 5 \text { with } \\
\text { "normal" class teachers) } \\
-8 \text { observations ( } 2 \text { in an integration class, } 2 \text { each in } 3 \\
\text { ordinary classes) } \\
\text { - document analysis }\end{array}$ & $\begin{array}{l}1 \text { school Canton } \\
\text { Neuchâtel: } \\
\text { - } 1 \text { interview with director }\end{array}$ \\
\hline $\begin{array}{l}\text { German-speaking } \\
\text { Switzerland }\end{array}$ & $\begin{array}{l}1 \text { school Canton Solothurn: } \\
\text { - } 1 \text { interview with the Teacher of the integration class } \\
\text { - document analysis }\end{array}$ & $\begin{array}{l}1 \text { school Canton } \\
\text { Solothurn: } \\
-2 \text { interviews with director } \\
\text { - } 4 \text { observations ( } 2 \text { each in } \\
2 \text { classes) } \\
\text { - } 6 \text { interviews with } 4 \\
\text { teachers } \\
\text { - document analysis }\end{array}$ \\
\hline
\end{tabular}

German-speaking schools, which would have been located respectively in an urban and in peripheral setting. We assumed that urban schools would have more experience with high diversity than peripheral schools, which turned out to be only partially true. However, given the limited time for the study, we had to adjust our expectations to the actual availability of school directors and teachers who reported being overwhelmed by their work. In the end, we gained access to the classes indicated in Table 1.

In what follows, names of schools and people are changed for anonymity purposes.

\section{Participants in the observed classrooms}

As can be seen from Table 1, detailed observations took place in three schools. As the analysis of these microsocial dynamics are at the heart of our attention in this paper, we need to further qualify these three schools, in regard with our research question-that is, the presence of mobile children. These schools are located in contrasting regions in Switzerland, two schools in a French speaking canton, and one in a peripheral setting (countryside/suburban) in a Swiss German speaking canton.

In the French-speaking canton, the two urban schools, while housed in different neighborhoods, belong to the same school district and are under the same management. Both are located in a large city whose population is highly diverse in terms of origins, languages and migration statuses. The school «Le Prunier » is a small primary school that accommodates around 150 students from kindergarten to 6 th grade (Harmos ${ }^{7}$, children aged 4 to 10 ). The school "Le Figuier" is a large primary school which accommodates around 800 students from the 3rd to the 8th grades (Harmos, children aged 6 to 12). These two urban schools are "very heterogeneous" according to criteria established by the Swiss Federal Statistical Office. According to the Deputy Director for Cycle 2 (i.e., 4th to 8th grades), the two schools welcome children of 20+ nationalities, mainly from Europe, Africa, and to a lesser extent from Asia and South America. Most are second generation immigrants. It is in the smaller school, "Le

\footnotetext{
${ }^{7}$ The inter-cantonal agreement on the harmonization of compulsory education (Concordat HarmoS) entered into force in 2009. It aims to harmonize at the national level the duration and the fundamental objectives of public schooling.
} 
Prunier," that the integration class for allophone newcomers is hosted. At the time of research, this class was comprised of 16 newcomers, allophone children aged 8-13 years, of which two were refugees of African origin and the others came from Europe. The two ordinary classes observed in "Le Figuier" were comprised of 17 students and 20 students respectively, of which 5 were recently arrived in Switzerland, 4 of whom had passed though the integration class before joining the ordinary class, the fifth, speaking French, being accepted directly in a normal class.

The school "Kirschbaum" is located in a Swiss-German canton and welcomes 250 pupils, from the first to the sixth primary school year. It is situated in a village near a city where there exists an International school. In each of the school classes, there is at least one and at most 6 pupils for whom Swiss-German or German is not the mother tongue. These allophone children are mostly from mobile groups that settled in Switzerland after they left their home country (in this case essentially migrants from Italy, former Yugoslavia, and Sri Lankan Tamils). In addition to the presence of such "traditional" migrant groups, three pupils arrived in the school without having any knowledge of the German language and could be considered as belonging to these families in repeated mobility, since they knew different contexts of education and their families were not necessarily intending to definitively settle in Switzerland. Regarding the socio-geographical context of the school, and according to school directors, such profiles can be expected to grow in number, due to different reasons: notably, the presence of an industry hiring highly-qualified workers - and thus contributing to the presence of new mobile families in the village - and the future closing of the international school in the neighboring city could lead to a growth in the number of pupils entering the school without any knowledge of German language. In the classes we observed, one of the classes counted 24 pupils in total, and among them eight did experience and/or master at least one foreign language at home (mostly Italian and Albanian), and the other was constituted of twenty pupils and seven of them were allophones (4 from Albanian-speaking communities, and 3 from Turkey).

\section{Method}

Data collection aimed at documenting each of our intended levels of analysis. We combined desk-research, informal observations in the schools, systematic observations in the classrooms, as well as interviews (informal as well as problem-based) with school principals and teachers (Cohen et al. 2000). Our data thus comprises education laws, school guidelines and documentation, field notes and photographs from observations, recorded and transcribed interviews, as well as researchers' personal diaries. Our collaboration with each school was initiated by two researchers (one senior and one junior); the fieldwork was then conducted by two junior researchers; analyses were performed by the whole team.

To document policies at the cantonal level, we analyzed federal education policies and reports; cantonal education policies and reports; initial teacher training curricula from qualification courses and catalogues ${ }^{8}$; and continuous teacher training offers from professional development course catalogues. These sources were then completed by interviews. To document policies and practices at the school level, we examined institutional regulations and guidelines. We also drew on the interviews with directors or headteachers $(N=3)$ and teachers

\footnotetext{
${ }^{8}$ In most Swiss cantons, teacher training is provided by regional higher education institutions for teacher training ("Hautes écoles pédagogiques") that run in parallel to, and often in collaboration with, universities. The canton of Geneva alone trains teachers at university.
} 
$(N=11)$. Our interview grid covered themes such as: who are the newly arrived and mobile children in the school; which policies are applied to orient their education; how is the issue of diversity addressed in classes; what expectations are there regarding mobile children; what teaching practices and didactic material are selected and why; what experiences have resulted from these situations and choices; and what suggestions do teachers and directors offer to improve the teaching and learning process with migrant and mobile children? To document practices within the classroom, we combined these interviews with 12 classroom observations, documented using observation grids and photography. Our analysis is thus built on a triangulation of sources of data and perspectives, across and within levels of analysis. With a dialogical understanding of the situation, it aimed at identifying recurrences and divergences across and within levels, and eventually, at capturing significant classroom practices. Researchers captured both the overall unfolding of the class and its activities, and critical incidents during which issues connected to language, cultural systems, or mobility were implicitly or explicitly addressed.

\section{Welcoming mobile children in Swiss public schools}

This section presents our main findings at the macro (educational policies), meso (school approach) and micro (classroom practices) levels.

\section{Educational policies concerning mobile children focus on language acquisition with an implicit deficit view}

This section is based on our comparison of legal texts in the two cantons in which the foregoing schools are located, complemented by interviews with school directors and teachers. It highlights four interesting points.

Firstly, educational policies in both cantons focus strongly and firstly on local language acquisition. Support measures and programs are dedicated to local language acquisition for "allophone" students. Interestingly in Switzerland, even Swiss students can become allophones when they move to another part of the country in which a different language is spoken (for example, German speakers moving to French speaking Switzerland, or Italian speakers moving to German-speaking Switzerland). In the official texts, allophone Swiss nationals and allophone foreign children are offered the same support programs and measures for linguistic acquisition.

In canton of Neuchâtel, Bylaw 410.512.3 ${ }^{9}$, from 2 July 2014 "concerning measures of adaptation and compensation destined for pupils in compulsory schooling with special educational needs" ${ }^{\prime 10}$ covers the needs of foreign (allophone) students under the category of "special education needs", by associating them with having "great difficulties in learning... social competence... or behaviour..." and thus being "unable to, any longer or only partially follow the ordinary school program" (our translation, see Annex 2 for relevant sections in French). This school policy takes place under a specific focus on the integration of foreign populations and protection of minorities in the canton, which favors "social cohesion" based

\footnotetext{
9 "L'Arrêté relatif aux mesures d'adaptation et de compensation destinées aux élèves de la scolarité obligatoire ayant des besoins éducatifs particuliers", dated 2 July 2014, was implemented during the school year 2014-2015.

${ }_{10}$ Source : http://rsn.ne.ch/DATA/program/books/rsne/htm/4105123.htm
} 
on flexible and variable cultural identities, over "integration" (understood as assimilation to the dominant population) (see the report of the Community for Integration and Multicultural Cohesion (CICM) from the Republic and Canton of Neuchâtel, 2013-2017 ${ }^{11}$, selected excerpts are presented in annex 3 in French).

In canton of Solothurn, the Ordonnance 413.617, from 7 May 1991 (Verordnung 413.617 « Verordnung über die Integration fremdsprachiger Kinder und Jugendlicher ${ }^{12}$ ) says that "allophone Swiss children and foreigners" are entitled to some support measures, which take the concrete form of language courses: intensive group courses for children in ordinary classes; integration classes for allophone children; or improvement group courses for children with specific deficits. This ordonnance is complemented by two reports - «Deutschunterricht als Zweitsprache: Zusammenstellung» (Volksschulamt 2016a) and «Flucht und Migration : Situierung August 2016» (Volksschulamt 2016b), 2016b) which state:

The general purpose of teaching German as a second language is to allow pupils who grow up with two or more languages, or who have little pre-knowledge of the German language, to join regular schooling. Students must acquire communication skills as quickly and completely as possible, in order to orient themselves and assert themselves in the school system. The ability to act and communicate includes spatial and linguistic orientation, orientation in life with two cultures, knowledge and skills in second language, independent learning and activity (Volksschulamt-Service of compulsory education-), Canton of Solothurn, 2016a p.1; 2016b, p.5)

So, all matters linked to having a mobile trajectory and the experience of diverse languages and cultural systems are dealt with through the lens of local schooling language acquisition. In that sense, the current policy remains in continuity with the observations made in the $80 \mathrm{~s}$ regarding the schooling of mobile/migrant and especially allophone children (Bell and Gurny 1989; Gretler et al. 1989). This also corresponds to a tendency reinforced at the legal level: if in the past, residency rights and nationality were dependent on a good mastery of the "Swiss way of life," the new legislation now demands a strong command of the local national language to be allocated residency or nationality (Di Donato et al. 2020). One may, however, wonder if this serves the trajectories of children with experience of mobility and an often existing proficiency in many languages. Do schools open up spaces for the diversity of children's languages, or do they focus exclusively on the local one? What are the consequences for these children, as well as for the Swiss sedentary children, of limiting the relevance of other languages and competences, despite the potential benefits of linguistic diversity in a globalized world?

Secondly, the provision of these support measures and programs is quite different within and between the two cantons. In the Swiss federal landscape, subnational variations between cantons in terms of "educational inequality" have been reported in the literature (Manatschal and Stadelmann-Steffen 2013). At the intercantonal level, the provision of planned measures for schooling migrant/mobile children is linked to a political interpretation of the concept of "integration." The Canton of Neuchâtel aims to "promote social cohesion" (art.1 of the cantonal law) by "adaptation measures which take into account the particular educational needs of the pupil" (art 7 of the law). Children with a mobility experience are included in Neuchâtel classes corresponding to their age. Meanwhile, the Canton of Solothurn aims to

\footnotetext{
${ }^{11}$ Source : https://www.ne.ch/autorites/DEAS/COSM/Organisation/Documents/RapportCICM-COSM2017.pdf

${ }^{12}$ Verordnung über die Integration fremdsprachiger Kinder und Jugendlicher Vom 7. Mai 1991 (Stand 1. September 2007). 413.671
} 
"overcome the educational difficulties conditioned by their environment, their foreign language and their bicultural environment" (Ordonnance 413.671, 2007). Children are integrated into Solothurn classes according to their age and skills. It is thus interesting to see that mobility and the mastery of other languages are implicitly understood as likely to create educational difficulties in Solothurn, while falling under the topic of social cohesion in Neuchâtel.

Next, the measures themselves are implemented differently in the two cantons. Both cantons require a minimum of 15 allophone students in the same school cycle to open an integration class in a given locality. The funding of these classes is shared by the canton and the host city. In the canton of Neuchâtel, educational policies for mobile children envisage fulltime integration classes, which provide up to 2 years of tailored instruction for the purpose of French-language acquisition. Children who do not reach a good-enough mastery of French within these 2 years might then be diverted to special education programs, in which foreigners are overrepresented (47\% of foreign students vs. $27 \%$ in the ordinary school system, according to the Federal Office for Statistics). However, this system is available only in the two biggest cities of the canton. In other places, allophone students are schooled in ordinary classrooms and can benefit from a few hours of additional French language support over the course of 2 years. Similarly, in the canton of Solothurn, integration classes are mostly available in urban settings where there are "enough" students who could benefit from them. But children are schooled in these programs only part-time (in parallel to being in ordinary classrooms for some lessons) or full time for a shorter period. DAZ courses (Deutschunterricht als Zweitsprache German as second language) for allophone students in ordinary classrooms are largely provided during a maximum of 5 years. So there are evident inter-cantonal and intracantonal educational inequalities, as these integration classes are not available everywhere and the extent of their provision varies considerably.

The integration classes mentioned are in direct continuation of the "segregated" classes or "sheltered spaces" discussed in the earlier literature in Switzerland (Doudin and Ramel 2009; Perregaux 2009; Shapiro and Ehtesham-Cating 2019), that have contributed to reinforcing social inequalities between migrant/mobile children and "native" Swiss (Coradi Vellacott and Wolter 2005; Rosenberg et al. 2003). However, "transitional" experiences may also support children with diverse trajectories (Cole 1996; Gutiérrez et al. 1999). The question therefore remains open: Are these integration classes offering a valuable transition space for mobile children, or do they participate in the reinforcement of segregation and inequality?

Thirdly, as already stated, in the canton of Neuchâtel, the "Bylaw concerning measures of adaptation and compensation destined for pupils in compulsory schooling with special educational needs" (Ordinance 410.512.3, 2014), ensures support measures for newcomer (allophone) children who are unable to follow "the ordinary school program" because of their presumed "great difficulties in learning...social competence... or behaviour...," without any direct attribution of these difficulties to their "foreign" linguistic or sociocultural origins. Meanwhile, in the canton of Solothurn, the law supports measures aimed at "overcoming the educational difficulties conditioned by their environment, their foreign language and their bicultural environment" (Ordinance 413.671, 2007). Nevertheless, both legal texts assume at least implicitly (like in canton of Neuchâtel), if not explicitly (like in canton of Solothurn) a "deficit view" regarding mobile children: they must catch up with the gaps and delays due to their status as foreigners. The focus of the support measures is on remediation, as was shown already in the 1990s and 2000s (Perregaux 1996, 2009). Neither the potential for exceptional academic achievements among mobile students, nor their personal strengths and mastery of multiple languages, or travelling experience, are recognized or valued. Again, one may 
wonder: What are the implications of such a deficit approach, by which children's often rich, diverse sets of competences, gained through various school and out-of-school experiences, are turned into weaknesses to be compensated?

Fourthly, no measure is offered for mobile children with an advanced educational background. The dominant view for mobile children is the remediation of their (cognitive, social and cultural) deficits. Whereas many of our interviewees recognize that some mobile children are highly educated compared to Swiss standards, depending on which part of the world they come from and what types of mobile trajectories they have had, these children are integrated into classrooms according to their age or local language mastery without additional measures or enhanced programs corresponding to their existing educational attainment levels, and are often placed in integration classes with no formal curriculum apart from language learning and some mathematics. In general, Switzerland offers limited measures for children with advanced knowledge or who show learning ease at school. Only children diagnosed as high potential (HP) and having behavioural or cognitive difficulties are directed to supplemental measures similarly labelled as "special education."

\section{School practices: the concerns of heterogeneity and equality}

Local practices in each specific school are shaped by educational policies (and local knowledge of legal bases), but also by their geographical or administrative situation (for example, the existence or not of an integration class, the profile of mobile children and families, etc.), as well as by the local historical circumstances shaping previous experience of the school with migration. We analyzed school policies as they emerged from the interviews with the school directors (head teachers), from official school documents, and from the support measures in place. Three key findings are highlighted.

To start with, mobility falls under the general umbrella of "heterogeneity" in the school directors' and teachers' perception of the challenges they experience in relation to having mobile children in the classroom. The heterogeneity of skills and needs of students is regarded as a challenge to the idea of "equal schooling for all," in which the same education should be provided to all students, whatever their nationality, migration status or family background. Many teachers seem to struggle with the need to provide an education that guarantees an equity of chances in terms of educational achievement within an equality framework (often translated as the need to treat all children the same). In parallel, school directors and sometimes teachers echo the concerns of some local families that their "normal" children should be offered "normal" schooling. Therefore, children with experience of repeated mobility may be apprehended as another factor contributing to the challenge of heterogeneity in the classroom that disturbs the traditional assumption of "normality." They are seen as requiring "additional work" from teachers, not as a potential enrichment or resource to the dynamics of the classroom. This view is expressed as follows by a Head of school:

Among newcomers last year there were considerable variations: for example, the students from Hong Kong and Russia that are "over-schooled" in relation to the norm here, in relation to their peers. But also a Somalian family, with a culture and a language very different from our own, who arrive in Switzerland after three years in a refugee camp in Ethiopia, with 7 children, the oldest being 14 years old and has not had a single full day of school until now. The needs of children from different origins varies as well: A Spanish or Portuguese child does not have the same needs as a child from Sri Lanka 
who has arrived in Switzerland to a class of 18 children after having previously experienced a class of 100 children or more. Such children are lacking not only the language of instruction but also the habits of learning, the mannerisms, the cultural competences, etc. that are needed to integrate, to navigate and to succeed in a Swiss classroom. Furthermore, at home, the students continue to receive an education in their culture of origin which influences the relationship between the child and the school. (...) We really have to take a case-by-case approach. (School director, Canton of Neuchâtel).

The concern of this school director extends from allophony to the child's and family's distance to school, which can create other "deficits" in terms not only of local language but also in terms of school "habitus" (Bourdieu 1980, 2002), reflected in both the child's and the parents' relationship to education and to the school. This director associated the challenges of heterogeneity stemming from foreignness with additional work for the school, as teachers must meet the needs "on a case-by-case basis," with the risk of professional exhaustion and feelings of powerlessness. The discourse of professional exhaustion when confronted to the demands of heterogeneity in general, and foreign (allophone) students in particular, is expressed by other teachers and directors in the two cantons.

Then, our analysis suggests that school directors differ significantly in terms of whether and why they take into account the family's history and future mobility projects when deciding upon the newcomer child's school orientation and integration. Who should be integrated (for example, the child alone or the whole family?) and who should help in this integration (the school alone or the school with the local communities?) are open questions.

Ways of proceeding to welcome mobile children and sometimes families are diverse but quite ritualized. Some school directors meet the parents and child before the first day at school, with the assistance of a community translator if needed. They may use documents that they designed themselves, as no official document exists. We have observed such practice in both cantons but not in all schools. On this basis, some directors may plan measures for the child, which may also involve the family, for instance by indicating supports and courses offered by the local communities. At least one school director explicitly considered that successful school integration is a collaborative achievement including families and local associations, a vision coined as "extended educational community" (Sanchez-Mazas et al. 2018). In the canton of Solothurn, this meeting helps orient the child to specific school measures (language support, integration classes, etc.), whereas in the canton of Neuchâtel, orientation has been previously made by the administration based on purely linguistic criteria. The process of welcoming the child and family is then in the hands of the teacher in charge, who meets the child and family. According to the teachers interviewed, the goal of this first meeting is to begin to build a good relationship between the parents and the school by answering their questions and showing some interest for their situation. Some teachers, especially in integration classes, may use selfmade documents to collect information about the family's mobility trajectory, and to assess the level of the child's reading ability in their mother-tongue. However, the information collected about the family and their plans are not shared nor discussed further with the school, nor used to adapt the child's school program.

Something which is really important for me and for many teachers, is taking into account this difference, their culture of origin, their background, their experience (...) to sometimes try to understand the children better. But never to adapt what we do, what we have to do. It's rather to show them how things work here in our society [« chez nous »], how we live here, and then trying to get them to want it also and trying to bring them 
along with us (...) [Knowing about their background] is more about getting an understanding that is helpful for us to take a step in their direction. (Assistant school director, Canton of Neuchâtel)

The orientation of the children is done mainly on the basis of the local language skills, with limited consideration of other skills, languages, personal or family projects; the school concern is primarily to identify and prepare for pedagogical difficulties (i.e., children with little socialization to school), not to identify strengths and prepare for pedagogical opportunities. The fact that these children may not stay for their whole education in Switzerland is rarely addressed. Relationships with the families are limited to the normal ways of communicating in the standard classroom, whereas the teachers in integration classes are actively seeking a pedagogical alliance with the families.

Lastly, it seems that cultural diversity and multilingual skills receive little to no recognition and support within the mainstream curriculum and agenda at the school level ${ }^{13}$. Our data suggests an ambivalent attitude among teachers in this respect. In ordinary classes, engagement with students' mobility trajectories depends greatly upon the personal attitudes and preferences of the teacher. The prescribed curriculum for Cycle 2 (grades 5-8) in Frenchspeaking Switzerland emphasizes Swiss history, culture, geography and economy. Little attention is given to the causes and effects of mobility in the modern world, issues of social and cultural belonging, or to the plurality and hybridity of cultural systems. Unless the teachers themselves are personally willing to focus on such issues, the learning program and activities in the classroom will not solicit other ("non-Swiss") cultural or linguistic knowledge that students may have acquired during their mobile trajectories or may use at home or when interacting with the world around them. Broad competencies such as "knowing how to handle with different people" are expected from pupils in the Swiss-German canton according to its regular curriculum. However, this does not seem to be declined in the official programs. A teacher from one of the German-speaking schools explained, however, that children tend to mention their multiple language skills more easily in second language courses (in this case, French): in this particular context, the teacher may acknowledge and learn from their pupil's diverse forms of knowledge. Moreover, as a teacher said, times of the year when families can contribute to the school life or when personal topics can be discussed are limited. Globalization and mobility are thus not addressed as an object of knowledge and shared reflection. A research in Switzerland suggests that teachers are not trained to address such issues with students as part of their standard curricula, and that in these conditions, interactions may become very difficult to handle (Grossen and Muller Mirza 2020; Muller Mirza 2016).

As a conclusion, our analysis suggests that the main school concern is to treat all children in a given class in the same manner, regardless of their origin or mobility trajectory. In consequence, minimal attention is given to the potential "strengths" of newly arrived mobile children - such as mastery of languages, advanced knowledge in sciences, knowledge, and skills in other domains including geography, humanities, and social sciences taught in other countries, or more personally acquired skills such as strategies and the resources to deal with change and adversity. Hence, it seems the concern to maintain an "equal" treatment towards all children seems to serve merely to silence or even suppress what is unique and indeed rich in "other" children. Interestingly, teachers interviewed in our study attributed the social and

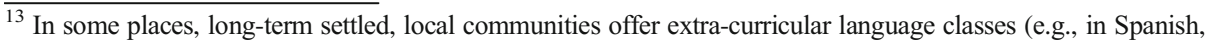
Portuguese, etc.). 
learning difficulties displayed by mobile children to both the individual aptitudes of the students and to their parents' relationship to the school (indeed to schooling in general), rather than to linguistic barriers, life experiences linked to their trajectory of mobility, their current situation, or the design of the schooling system itself.

\section{Contrasted practices within the classroom}

Although our exploratory observations were conducted over a short period (from Mars to June 2019) and in only seven classrooms (12 observations in total), they allow us to make two claims regarding how these teachers welcome mobile children in their classrooms.

On the one hand, teachers reported a general lack of formal training on how to engage with cultural and linguistic diversity in the classroom. These topics have not been formally part of the mandatory basic training of the teachers we met, as also observed in a study on teachers' representation (Schertenleib 2014). Therefore, there seems to be a very unequal access among teachers to knowledge on how to include students with different backgrounds and languages in the classroom. Some of the teachers decided to study these questions in a 2-year continuing professional education (Master's level) course. The time investment required by this highquality, focussed training course requires a high motivation among participating teachers and, even then, will seem prohibitive for many who want and need the training.

In consequence, use of personal support networks, online resources and tinkering among teachers, especially in integration classes, to create pedagogical material for foreign students, has been repeatedly observed. Many of the activities and solutions for differentiating instruction in order to meet the needs of mobile and migrant students were imagined and designed by the teachers themselves. More experienced colleagues (and the tools or documents that they have previously designed) seem to be the main resources for teachers facing issues of culturally diverse classrooms.

On the other hand, our observations revealed significant contrasts between teaching practices in integration classes versus those in ordinary classes. As we have seen, there have been heated debates about the status of these "sheltered spaces," seen by some as reinforcing segregation and preventing students from achieving high-academic standards, and by others as a rather useful transitory setting. Our observations show that the place of the integration classes is not always clear within schools: they are sometimes included, sometimes excluded from ordinary school life (socially, but also sometimes physically). However, our observations also suggest that these classes may offer an inspiring space for experimentation and innovation. Such experimentation can take place thanks to the high engagement and creativity of the teachers in charge, and also because they are released from many of the curricular constraints that are imposed on ordinary classes (given that there are no achievement obligations during this period apart from French and Maths). Support measures such the DAZ hours similarly appear as potentially innovative spaces in which teachers might try new pedagogical tools or ideas. Therefore, integration classes appear to be interesting spaces of innovation for teaching culturally diverse children - and some of their innovations could be used for teaching all students, whatever their linguistic or national background.

In this respect, we would like to highlight key features of these innovative spaces: coteaching, partial release from the standard curriculum and creativity in the design and use of didactic material, allow individualized teaching and learning, with a simultaneous focus on connecting the children to the school, by establishing relation between children's spheres of experiences and recognition of children's previous skills. 
As one integration class teacher said, "we have 16 students and... 16 different programmes." This flexibility is being facilitated by a co-teaching arrangement and by the lack of constraining curriculum, as well as by material conditions. Flexible workspaces and groupings enable peer-learning and self-paced autonomous work, in addition to whole group instruction. Peer support has been occasionally observed in the learning process, sometimes in foreign languages. Individualized teaching and learning simultaneously encourage autonomous learning and work in small groups:

There are 16 different programmes. In fact, certain principles [guide the work] in the class: [for example] that students should be as autonomous as possible in order to freeup time so that [I can] revisit/rework things with small groups of students. As such, they have certain things they are supposed to do over the course of the week: computer activities, exercises, etc. Overall, it is in these moments where they can generally work alone. Then I have groups of 4 to 6 students, for example for reading or for workshops. It was my predecessor who organized much of this. In order to organize half-classes in the afternoons, there is one teacher here in the class and another who goes with the other half group to, for example, gymnastics. Then on other days, one or the other group goes to do manual activities (...) This is really only possible because we work together as coteachers. We try to regularly touch-base with each other...to look at everything, such as little breakthroughs and also difficulties. Lately there have been 2-3 students for whom telling the time is quite difficult...So, after noticing this, we try to respond quickly. The next day I take this small group and try to address these themes... see if we can work in a focused way on that. I don't know yet how we're going to manage it next year. It's really going to change. Next year there is no more money [for co-teaching]... Next year, one of us will be laid off. This year I received enough support, I find it has been quite good. But next year, I think it will be quite insufficient. It's going to be, yes, difficult. (Teacher, integration class)

In contrast to the ordinary class where monolingualism is the norm, the integration class gives a special status to the diversity of languages spoken by children. These classes are indeed multilingual, with foreign languages being actively used and socially recognized in the teaching and learning process. Teachers make some use of students' existing linguistic knowledge to help them learn the local language. In the example below (Fig. 1), the handwritten tabs introducing the children to French spatial prepositions (on, behind, under, etc.) has been translated with the help of the children themselves. The teacher draws on the previous linguistic knowledge of the children to help them learn French by connecting the unknown (French terms) to the known (grammatical use and terms in their own language). Consequently, this exercise makes a publicly valued space for the home languages and linguistic knowledge of the children, which could encourage students' participation and understanding (Gutiérrez et al. 1999; Warren et al. 2001).

Both the integration classes and the DAZ classes that we observed were offering a form of "third space." By this, we mean a relatively protected institution frame, where a different quality of relations and engagement is possible, and others tasks and activities are proposed than in the usual classroom - something between class and leisure, or class and home, or learning and playing (Cole 2019; Gutiérrez et al. 1999). In these classes, teachers could work in pairs, and could thus be partly released from some of the obligations of the curriculum. With small numbers of students, they could develop innovative materials, and use resources advised by more experienced peers. In their "bricolage" to propose activities tailored for the children's 


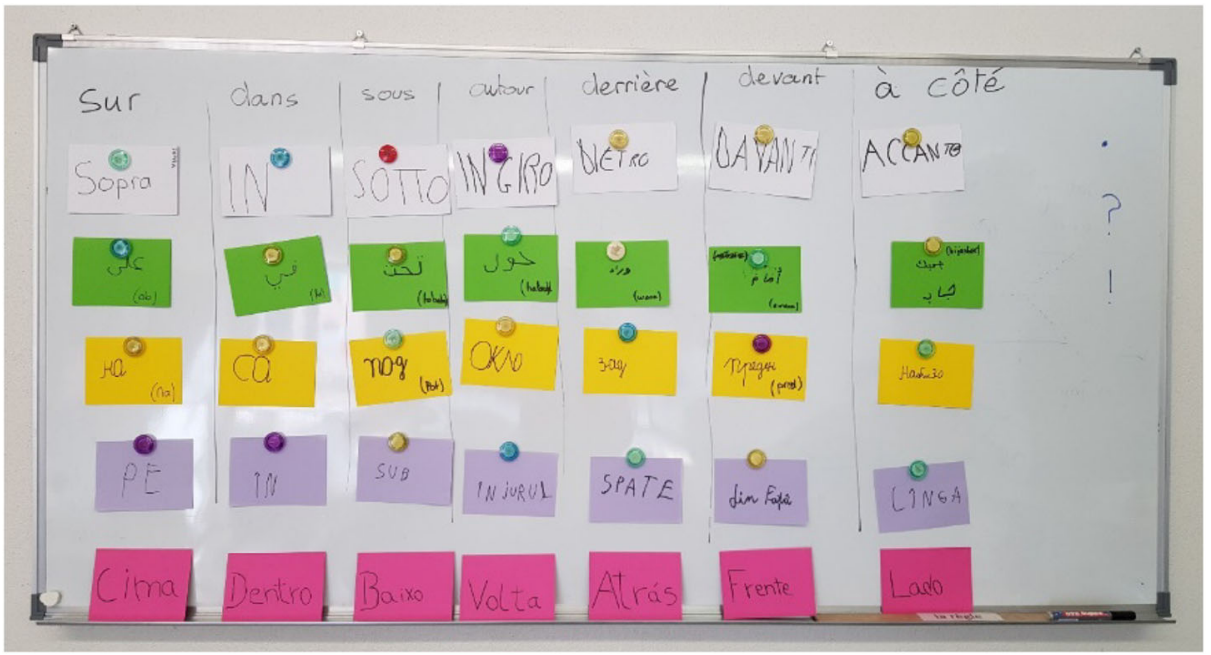

Fig. 1 Multilingual display of prepositions translated with the assistance of students in the integration class

need, teachers were thus creating a space of hybrid didactic and ludic exploration (Cole 2019). These activities themselves seemed to support children's ability to use knowledge across spheres of experience, mainly drawing on languages but also knowledge mastered outside of the class, in their daily lives, and at different stages in their mobility story (Gutiérrez et al. 1999). Doing so, teachers provide resources for children to create a sense of continuity, so crucial for identity and wellbeing in the experience of mobility and, by offering recognition of their skills, provide support to children's own personal sense-making of knowledge (Zittoun 2014; Zittoun and Grossen 2012).

\section{Discussion}

Our analysis, informed by a sociocultural psychology approach, aimed at answering the general question of how mobile children are welcomed in Swiss schools, and especially, how these schools offer special measures to account for students' past and future mobility trajectories. Our findings highlight contrasts, continuities, and contradictions between educational policies at the cantonal level, across school policies and practices at the organizational and classroom levels, and in interactions that account only narrowly for the realities of mobile children.

At the macrosocial level, educational policymakers seem to consider only one form of mobility, that of migrants settling in Switzerland. This does not take into account the changing reality of mobility patterns, that is, the fact that an increasing number of people stay in the country only temporarily. Those with repeated mobility experience range from highly qualified professionals to refugees with disrupted educational pathways. At present, the legal demands applied to people who want to obtain residency rights or Swiss citizenship require that children should master the language and become "integrated" in Switzerland (Di Donato et al. 2020). Migration is thus seen as an obstacle or problem to be fixed by education, mainly through the acquisition of the local schooling language. The means by which this is achieved varies across Cantons, leading to intercantonal inequalities. 
At the meso-level of school practices, the picture becomes more complex. According to official texts, limited linguistic support is offered in ordinary classrooms and integration classes for allophone students. Provision varies across communes as funding for integration classes is dependent on the number of registered pupils. Here again, intra-cantonal inequalities appear. The deficit view, which is present in legal texts, is reflected in the representations voiced by the school directors. Mobility is not approached as a strength for the student nor for the school, but as yet another factor adding to the heterogeneity of the classroom that makes life "difficult" for teachers. Newly arrived students must therefore be distributed across classrooms to balance the additional workload their presence entails and to maintain as much as possible a "normal" learning situation for the other students. Concerns for equity (among teachers) and equality (for the students and families) are predominant in the remarks of school directors. The extent to which the school considers the family's past and future mobility experiences, including their educational history and aspirations, is discretionary and depends on the personal sensitivity and experience of the school director. Similarly, school-family relations, which are absent from policy texts, are highly present in the discourses of some school directors and teachers. While the administration of welcoming focuses on assigning children to either "normal" or integration classes based on an assessment of linguistic deficiency, school practices encompass additional aspects including extending welcome processes to the family unit so that parents and siblings can also benefit from being socialized into the realities of the Swiss schools and life.

In this context, we have seen teachers reporting a lack of training on diversity and how to engage with it into their classroom practices. Official curricula in Switzerland address only minimally the themes of globalization, mobility, and diversity at the primary school level. Without an adequate educational framework, teachers who want to give greater consideration to the mobility experiences of their students, including the unique knowledge and skills they have acquired in different contexts, eventually create their own interview practices and pedagogical tools for this purpose. Innovative practices to help students connect to the language and activities of the school are developed in the margins of the official texts. Interestingly, integration classes which have been released from some of the constraints of ordinary classrooms (including the pressure of curriculum standards), become, in some cases, spaces of pedagogical innovation. Indeed, some teachers manage to create "third spaces" in which improvisation and creativity seem to better support mobile children's learning and development. Among these innovations, we highlighted the following: (1) the flexible use of space and co-teaching practices as means for promoting better individualized teaching and autonomous learning; (2) opening spaces within the school to bridge personal and family experiences around meaningful activities; and (3) the valorisation of linguistic diversity through multilinguistic activities. We hypothesize that pedagogical strategies might be a first answer to overcome the implicit deficit view underlying current texts and discourses around mobile students in public schools. Such strategies offer opportunities to foreground the diverse strengths of mobile children, instead of considering only their limitations with respect to standard achievement expectations. We believe these three key elements could help improve teaching and learning environments in public schools for all children, not only those in repeated mobility.

This reading suggests two final analytical comments, one about the weaknesses of current provisions for mobile students, and the other, about the qualities of these "third spaces." 
On the one hand, our reading suggests that schools in Switzerland are still far from finding a consistent response to the needs of children in repeated mobility, in part because of the absence of engagement with these questions in current educational guidelines. A second reason appears to be the observed general reluctance among school directors and teachers to consider family mobility projects at the time of enrolment. Even when this is done, it tends to have little impact on the definition of the child's educational program. Parents sometimes find it difficult to communicate these intentions, needs and questions, especially if they do not master the local language. This limited relationship with the school may affect parents' room for action and decision-making, notably during orientation phases (de Haan and Wissink 2013; Elbers and Haan 2014). A third reason is that school programs themselves appear to be still based on the idea of a sedentary national population, with little room to address the realities of globalization, human mobility, and the diversity of cultural systems and histories. A fourth reason is that teachers seem poorly prepared to welcome mobile children, with little knowledge about the diversity of forms of mobility that predominate today, and the possible adaptations they can make to meet the challenges and opportunities brought by cultural and linguistic diversities in their classes. Based on our fieldwork, we believe that such issues deserve to be included in teachers' basic training.

In addition to the foregoing, the focus on language acquisition and on ensuring "equality of treatment" means that mobile children are offered little opportunity to valorize their existing knowledge and to develop in the domains in which they have expertise ahead of the other students. This represents a loss for both the newly arrived and existing children in the classroom who could benefit from knowledge exchange and individualized learning pathways. What we conclude from our exploration, therefore, is that the school system currently does not know how to prepare children whose families are likely to leave Switzerland after a few years for their future mobility. The impression of not being understood by the schools, or the fear that their children are not developing the skills that would be required to join desired educational tracks in other countries, may thus bring families in repeated mobility to withdraw their children from public schools (Levitan 2019).

On the other hand, we have observed the interest and strength of certain local initiatives in special settings, which we have coined "third spaces." It is interesting to reflect on how these initiatives correspond to some features identified in the sociocultural psychology and educational research literature. Studies suggest that in order to engage in school tasks, children need to make sense of the situation (Rochex 1998). For children coming from families or daily life conditions whose sociocultural norms differ from what they find in the classroom, sense-making can be supported by helping the child to create links across spheres of experience, be it through activities, the circulation of symbolic resources and objects, the student's language skills, or the sense they confer upon activities (Akkerman and Bakker 2011; Crafter 2011; Crafter et al. 2017; Grossen et al. 2012; Mehmeti and Zittoun 2019; Moll et al. 1992; Zittoun and Grossen 2012). Another way to improve the learning environment for students is to create spaces of a more ludic or aesthetic character, between learning and playing, that support children's engagement and the acquisition and development of skills (Cole 1996, 2019; Gutiérrez 2008; Mehmeti and Perret-Clermont 2016; Walker 2014). All-in-all these connections highlight the importance of recognition, within the school, of children's specific life experiences, the languages they master, and the diverse skills and capacities they possess that are not normally acknowledged at school (Gutiérrez 2008; Gutiérrez et al. 1999). Research has also emphasized the importance of 
family-school dialogue and exchange. Children as learners are not isolated beings; they belong to a specific relational entity with a its own history, norms, and projects. In various ways, family school communication and collaboration with families can support and foster the children's educational progress (Akkerman and Bakker 2019; Bronfenbrenner 1986; Marsico et al. 2013). Regarding the teaching-learning situation itself, our work has shown the importance of the quality of the institutional framework or dispositive that have a "transitional" function, that is, that accompany children or learner in their transitions to a new institutional setting. Under certain conditions, teachers can create frameworks that afford a safe enough "thinking space" (Perret-Clermont 2004, 2015), that welcome learners from an insecure positions, providing them with social recognition, acknowledging their personal skills and strengths, tolerating trials and errors, and therefore supporting both their identity and learning in the transition process (Zittoun 2004; Zittoun and PerretClermont 2009). Such settings prepare children for departing and arriving, which is achieved when the two settings conscientiously interact and coordinate the student's experience (Zittoun 2006, 2016).

Our reading thus suggests that some initiatives proposed to welcome and support mobile children (whether integration classes or support programs like DAZ courses) have many of these transitional qualities of "third spaces." While acknowledging the risk that sheltered spaces on the margins of the main school program can hinder the future educational trajectory of some children, effective third spaces can also offer certain advantages. Ideally, they acknowledge the skills and knowledge that children have developed in various spheres of experience; they consider the family's past trajectory and future plans, and they provide a safe thinking space for the children. The effectiveness of such third spaces depends heavily, however, on teachers' commitments and creativity, and also on whether financial resources allow teachers to treat the children in their singularity. These features could facilitate the inclusion of children in certain school systems in a large variety of situations, not necessarily only those connected to situations of repeated mobility.

There may be other specific educational arrangements that are beneficial for welcoming mobile children. In this respect, the long expertise of international schools in welcoming the children of families in repeated mobility may offer additional insights (Hayden and Thompson 1995). However, while there is a growing body of research on the management, curricula and clientele of international schools (Bates 2010), including the identityformation and cultural adaptation of their globally mobile students and teachers (Grimshaw and Sears 2008; Hacohen 2012; Langinier and Gyger Gaspoz 2015), we found less accessible research on the specific pedagogical strategies, activities and resources that they use to accompany the arrival and transition of newcomer students and their families. These deserve, in our view, to be further researched, highlighted, encouraged, and supported.

Limitations to our study include the small number of classes documented, the lack of interviews with relevant officials needed to probe questions of educational policies, and the lack of perspectives from the children and the families. All this is anticipated for a future phase of research. Finally, the interviews and observations were conducted over a short period of time and therefore represent more of a 'snapshot' than a developmental perspective that we feel would be important for fully elaborating our case studies. Nevertheless, we believe that, given its multi-layered approach, this fieldwork enables us to highlight some interesting dimensions - and the complexity of the continuities and discontinuities between our different levels of analysis. 


\section{Conclusion}

Switzerland is a small country on the world map, yet an important player in international exchanges and relations. As one of the European countries with the highest rates of migrants per capita, it can also be seen as a small laboratory when it comes to changes in mobility patterns and in the measures developed to address them. Hence, we hope that our work on institutional responses to the increasing number of children in repeated mobility also raises questions which may have a more general scope. First, when it comes to the issue of inclusion of children at school, we invite educational actors to move away from a focus on the child's individual skill deficiencies and to take a more systemic perspective on the institutional and relational settings in which children are welcomed. One may thus ask, beyond the issues met by children at school, what are the larger contradictions within the system generating difficult teaching-learning situations? Second, we invite educational actors to consider mobile children beyond the legal or administrative definition of the migratory status of their families. Rather, we propose that attention be given to the specificity of the mobility experiences of children. One may ask, what are the social, linguistic and creative skills children learn and develop in the course of mobility experiences, and how to draw on them when designing school programs? Third, we invite a reopening of the question of integration when it comes to school life; after all, mobile children, who may not settle in the country for a long time, bring about new questions for classrooms and the educational system. How can we learn from the experience of children? How can children's specific and diverse experiences contribute to the transformation and enrichment of the school's shared knowledge - what it teaches, and how it conceives itself? By these reflections, we hope to have shown that a consideration of how schools welcome mobile children may invite us to question some of the basic assumptions about purposes underlying learning and instruction.

\section{Annex 1 Five dimensions for the analysis of school policies}

1. Emerging conceptions of migration and mobility

2. Relations with the family

3. Orientation and first day of school

4. Special measures in place
1.1. How do headteachers / directors understand the terms migration and mobility?

1.2. How do they describe the process for the school integration of migrant/mobile children?

1.3. Which challenges do they associate with the school integration of migrant/mobile children?

2.1. How does the school organize the first contact with the child/the family?

2.2. How is the family project taken into account into the plans of the school for the integration of this child?

2.3. How does the school communicate with the family later on?

3.1. Which is the process through which the child is oriented to a specific school/school level/ordinary classroom/special class?

3.2. Which information and criteria are taken into account for the orientation decision?

3.3. Which information and instructions are given to the teachers when a migrant/mobile child first arrives in their classroom?

4.1. Which special measures are in place in this school for migrant/mobile children? How do they implement/complement the support measures described in the law? 

1. Emerging conceptions of 1.1. How do headteachers / directors understand the terms migration and migration and mobility mobility?

4.2. How do children go in and out of these special measures?

5. Teachers' training and support 5.1. How have the local teachers been trained regarding integration of migrant/mobile children?

5.2. Which resources are available for the teachers working with mobile/migrant children?

5.3. Are there events, meetings, training planned for the teachers working on these topics?

\section{Annex 2. Arrêté 410.512.3 du canton of Neuchâtel, du 2 juillet 2014, article 2}

Art. 2 Au sens du présent arrêté, on entend par:

a) élèves ayant des besoins éducatifs particuliers: les élèves qui rencontrent de grandes difficultés en matière de facultés d'apprentissage ou de réalisation, de compétences sociales ou de comportement et qui ne peuvent pas, plus, ou seulement partiellement suivre le programme de l'école ordinaire;

b) mesures d'adaptation: les mesures d'aménagement, les mesures de soutien et les mesures techniques;

c) mesures d'aménagement: les mesures qui consistent en l'adaptation du travail en classe par l'enseignant-e notamment par la mise en œuvre d'un programme scolaire adapté, par le biais de consignes, d'exercices différenciés et de temps supplémentaire;

d) mesures de soutien: les mesures qui consistent en un soutien pédagogique ordinaire ou spécialisé, un soutien à l'intégration, un soutien par le mouvement ou un soutien langagier;

\section{Annex 3 Report of the Community for Integration and Multicultural Cohesion (CICM) from the Republic and Canton of Neuchâtel, 2013-2017}

\section{Selected parts (Section "Politique interculturelle à Neuchâtel", p.5)}

Le canton de Neuchâtel a inscrit l'intégration des personnes étrangères et la protection des minorités comme une tâche étatique ${ }^{14}$, principe appuyé dans sa loi sur l'intégration et la cohésion multiculturelle. La spécificité du canton de Neuchâtel réside dans une approche interculturelle en matière de politique d'intégration (s'appuyant sur les principes de diversité, égalité et dialogue)... Le but de la politique interculturelle neuchâteloise, tel qu'inscrit dans la loi cantonale sur l'intégration et la cohésion multiculturelle [Ordonnance 132.04, daté du 26 août 1996$]^{15}$ n'est pas l'intégration mais la cohésion sociale, l'égale dignité et le bien-être de chacune et de chacun. L'intégration, quant à elle, est un processus réciproque qui implique d'une part la responsabilité individuelle et d'autre part l'ouverture de la société d'accueil. Elle part du principe que les identités et les cultures sont multiples et variables et que, non figées, elles évoluent au contact les unes des autres. Ceci vaut aussi pour la(les) culture(s) majoritaire(s).

\footnotetext{
${ }^{14}$ Source : Constitution de la République et Canton de Neuchâtel (Cst. NE), September 2000, art 5. al. d.

${ }^{15}$ Source: http://rsn.ne.ch/DATA/program/books/rsne/htm/13204.htm
} 
Acknowledgements We wish to thank the school directors, teachers, and children that opened their doors to our enquiry and accepted to share their experiences and their daily activities.

Funding Open Access funding provided by Université de Neuchâtel. This research project was supported by a grant from the nccr on the move program.

Laure Kloetzer. Institute of Psychology and Education, University of Neuchâtel Espace Tilo-Frey 1, 2000 Neuchâtel, Switzerland. Email: laure.kloetzer@unine.ch, website: www2. unine.ch/ipe

Sara Clarke-Habibi. Institute of Psychology and Education, University of Neuchâtel Espace Tilo-Frey 1, 2000 Neuchâtel, Switzerland. Email: sara.clarke-habibi@unine.ch

Teuta Mehmeti. Institute of Psychology and Education, University of Neuchâtel Espace Tilo-Frey 1, 2000 Neuchâtel, Switzerland. Email: teuta.mehmeti@unine.ch

Tania Zittoun. Institute of Psychology and Education, University of Neuchâtel Espace Tilo-Frey 1, 2000 Neuchâtel, Switzerland. Email: tania.zittoun@unine.ch

Open Access This article is licensed under a Creative Commons Attribution 4.0 International License, which permits use, sharing, adaptation, distribution and reproduction in any medium or format, as long as you give appropriate credit to the original author(s) and the source, provide a link to the Creative Commons licence, and indicate if changes were made. The images or other third party material in this article are included in the article's Creative Commons licence, unless indicated otherwise in a credit line to the material. If material is not included in the article's Creative Commons licence and your intended use is not permitted by statutory regulation or exceeds the permitted use, you will need to obtain permission directly from the copyright holder. To view a copy of this licence, visit http://creativecommons.org/licenses/by/4.0/.

\section{References}

Adams, M. (2016). Young expatriate children forming friendships: A cultural-historical perspective. International Research in Early Childhood Education, 7(1), 85-105 http://files.eric.ed.gov/fulltext/ EJ1138859.pdf.

Adams, M., \& Fleer, M. (2016). Social inclusion and exclusion of a young child: A cultural - historical perspective of an international mid-semester transition into an international school in Malaysia. Australasian Journal of Early Childhood, 41(3), 86 http://search.informit.com.au/documentSummary; dn= 461667573090018;res=IELHSS.

Akkerman, S. F., \& Bakker, A. (2011). Boundary crossing and boundary objects. Review of Educational Research, 81(2), 132-169. https://doi.org/10.3102/0034654311404435.

Akkerman, S. F., \& Bakker, A. (2019). Persons pursuing multiple objects of interest in multiple contexts. European Journal of Psychology of Education, 34(1), 1-24. https://doi.org/10.1007/s10212-018-0400-2.

Bates, R. (2010). Schooling Internationally: Globalisation, Internationalisation and the Future for International Schools (1st ed.). Routledge.

Becker, R., Jäpel, F., \& Beck, M. (2011). Statistische und institutionelle Diskriminierung von Migranten im Schweizer Schulsystem: Oder werden Migranten oder bestimmte Migrantengruppen in der Schule benachteiligt? Schweizerischer Dokumentenserver Bildung. Universität Bern http://edudoc.ch/record/96257.

Belin, J. R. (2018). The motivation for repeated mobility in highly-skilled Germans. (doctoral dissertation) http:// minerva-access.unimelb.edu.au/handle/11343/218116

Bell, N., \& Gurny, R. (1989). L'acquisition d'une langue seconde par les immigrants. Application des nouvelles tendances en sociologie et en psychologie sociale de la langue à l'analyse de la situation des travailleurs étrangers en Suisse. In A. Gretler, R. Gurny, A.-N. Perret-Clermont, \& E. Poglia (Eds.), Etre Migrant. Approches des questions socioculturelles et linguistiques relatives aux enfants migrants en Suisse (2e, original 1981 ed., pp. 103-146). Peter Lang.

Bourdieu, P. (1980). Le Sens pratique.Les Editions de Minuit.

Bourdieu, P. (2002). Questions de sociologie (Original 1984). Les Editions de Minuit.

Bronfenbrenner, U. (1986). Ecology of the family as a context for human development: Research perspectives. Developmental Psychology, 22(6), 723-742. https://doi.org/10.1037/0012-1649.22.6.723.

Cabra, M., \& Zittoun, T. (2021). Modes of engagement: A sociocultural approach to institutions. In K. Komatsu (Ed.), The self on the move: Passing through institutional settings. Information Age Publishing.

Caligiuri, P. M., Hyland, M. M., Joshi, A., \& Bross, A. S. (1998). Testing a theoretical model for examining the relationship between family adjustment and expatriates' work adjustment. Journal of Applied Psychology, 83(4), 598-614. https://doi.org/10.1037/0021-9010.83.4.598.

Cangià, F. (2017). (Im)Mobility and the emotional lives of expat spouses. Emotion. Space and Society, 25, $22-$ 28. https://doi.org/10.1016/j.emospa.2017.10.001. 
Cangià, F. (2018). Precarity, imagination, and the mobile life of the 'trailing spouse'. Ethos, 46(1), 8-26. https:// doi.org/10.1111/etho.12195.

Cangià, F., \& Zittoun, T. (2018). When "expatriation" is a matter of family. Opportunities, barriers and intimacies in international mobility. Migration Letters, 15(1), 1-16 http://www.tplondon.com/journal/index.php/ml/ article/view/977.

Canton of Solothurn (2016a). Deutschunterricht als Zweitsprache. Zusammenstellung.

Canton of Solothurn (2016b). Flucht und Migration : Situierung, August 2016.

Cassée, P., Gurny, R., \& Hauser, H.-P. (1989). Les difficultés scolaires des enfants étrangers: Destin de la deuxième generation ou conséquence de la politique de l'immigration. In A. Gretler, R. Gurny, A.-N. PerretClermont, \& E. Poglia (Eds.), Etre Migrant. Approches des questions socioculturelles et linguistiques relatives aux enfants migrants en Suisse (2e, original 1981 ed., pp. 221-234). Peter Lang.

Centlivres, P. (1990). Intégration et naturalisation. L'exemple suisse. Terrain. Anthropologie \& sciences humaines, 15, 135-144. https://doi.org/10.4000/terrain.2990.

Cesari-Lusso, V. (2001). Quand le défi est appelé intégration: Parcours de socialisation et de personnalisation de jeunes issus de la migration (L. Oppizzi, Trans.). Peter Lang.

Cohen, P. L., Manion, L., \& Morrison, K. (2000). Research Methods in Education (5th Revised edition). Routledge Falmer.

Cole, M. (1996). Cultural psychology. A once and future discipline. Harvard University Press.

Cole, M. (2019). Re-covering the Idea of a Tertiary Artifact. In A. Edwards, M. Fleer, \& L. Bøttcher (Eds.), Cultural-Historical Approaches to Studying Learning and Development: Societal, Institutional and Personal Perspectives (pp. 303-321). Springer Singapore. https://doi.org/10.1007/978-981-13-6826-4_20.

Cole, M., \& Engeström, Y. (2007). Cultural-historical approaches to designing for development. In J. Valsiner \& A. Rosa (Eds.), Handbook of sociocultural psychology (pp. 484-507). Cambridge University Press.

Consortium PISA.ch. (2010). PISA 2009: Les élèves de Suisse en comparaison internationale. Premiers résultats. OFFT/CDIP et Consortium PISA.ch.

Consortium PISA.ch. (2019). PISA 2018: Les élèves de Suisse en comparaison internationale. OFFT/CDIP et Consortium PISA.ch. http://pisa.educa.ch/sites/default/files/20110111/pisa2009_fr.pdf

Coradi Vellacott, M., \& Wolter, S. (2005). Chancengerichkeit im schweizerischen Bildungswesen. Aarau: Schweizerische Koordinationsstelle für Bildungsforschung.

Crafter, S. (2011). Parental cultural models and resources for understanding mathematical achievement in culturally diverse school settings. Educational Studies in Mathematics, 81(1), 31-46. https://doi.org/10. 1007/s10649-011-9359-5.

Crafter, S., Cline, T., Abreu, G. de, \& O’Dell, L. (2017). Young peoples' reflections on what teachers think about family obligations that conflict with school: A focus on the non-normative roles of young caring and language brokering. Childhood, 24, 517-530. http://oro.open.ac.uk/49268/

Cresswell, T. (2006). On the Move: Mobility in the Modern Western World (1st ed.). Routledge.

D'Amato, G. (2010). Switzerland A multicultural country without multicultural policies? In S. Vertovec \& S. Wessendorf (Eds.), The multiculturalism backlash: European discourses, policies and practices. Routledge.

Dahinden, J. (2009). Are we all transnationals now ? Network transnationalism and transnational subjectivity : the differing impacts of globalization on the inhabitants of a small Swiss city. Ethnic and Racial Studies, $32(8), 1365-1386$.

Dahinden, J. (2012). Transnational Belonging, Non-ethnic Forms of Identification and Diverse Mobilities: Rethinking Migrant Integration? In M. Messer, R. Schroeder, \& R. Wodak (Eds.), Migrations: Interdisciplinary Perspectives (pp. 117-128). Springer. https://doi.org/10.1007/978-3-7091-0950-2_11.

Dahinden, J. (2016). A plea for the 'de-migranticization' of research on migration and integration. Ethnic and Racial Studies, 39(13), 2207-2225. https://doi.org/10.1080/01419870.2015.1124129.

De Abreu, G. (2000). Relationships between macro and micro socio-cultural contexts: Implications for the study of interactions in the mathematics classroom. Educational Studies in Mathematics, 41, 1-29.

de Haan, M., \& Wissink, I. (2013). The interactive attribution of school success in multi-ethnic schools. European Journal of Psychology of Education, 28, 297-313. https://doi.org/10.1007/s10212-012-0115-8.

Di Donato, F., Lavanchy, A., Levasseur, E., Mahon, P., \& Zittoun, T. (2020). La fabrique de la nationalité. In Anthropos.

Doudin, P.-A., \& Ramel, S. (2009). Intégration et inclusion scolaire. Du déclaratif à leur mise en oeuvre. Revue des HEP de Suisse romande et du Tessin, 9, 9 https://orfee.hepl.ch/handle/20.500.12162/1276.

Elbers, E., \& de Haan, M. (2014). Parent-teacher conferences in Dutch culturally diverse schools: Participation and conflict in institutional context. Learning, Culture and Social Interaction, 3(4), 252-262. https://doi.org/ 10.1016/j.lcsi.2014.01.004

Engeström, Y. (2008). Weaving the texture of school change. Journal of Educational Change, 9(4), 379-383. https://doi.org/10.1007/s10833-008-9086-6. 
Engeström, Y., Kajamaa, A., \& Nummijoki, J. (2015). Double stimulation in everyday work: Critical encounters between home care workers and their elderly clients. Learning, Culture and Social Interaction, 4, 48-61. https://doi.org/10.1016/j.lcsi.2014.07.005.

Felouzis, G., \& Charmillot, S. (2013). School tracking and educational inequality: A comparison of 12 education systems in Switzerland. Comparative Education, 49(2), 181-205. https://doi.org/10.1080/03050068.2012.706032.

Felouzis, G., \& Charmillot, S. (2017). Les inégalités scolaires en Suisse. Social Change in Switzerland, 8. https:// doi.org/10.22019/SC-2017-00001.

Felouzis, G., Charmillot, S., \& Fouquet-Chauprade, B. (2016). Les élèves de deuxième génération en Suisse: Modes d'intégration scolaire et compétences acquises dans 13 systèmes éducatifs cantonaux. Swiss Journal of Sociology, 42(2), 219-244. https://doi.org/10.1515/sjs-2016-0010.

Furrer, J., Christin, T., OFS; Efionayi-Mäder, D., Farago, P., Fleury, S., Heiniger, M., Moeschler, O., Priester, T. \& Suter, C. (2020). Panorama de la société suisse. Migration, intégration, participation. Office Fédéral de la Statistique, Université de Neuchâtel, Université de Fribourg (Eds).

Flyvbjerg, B. (2011). Case study. In N. K. Denzin \& Y. S. Lincoln (Eds.), The Sage Handbook of Qualitative Research (4th ed., pp. 301-316). Sage.

Gomensoro, A., \& Bolzman, C. (2015). The effect of the socioeconomic status of ethnic groups on educational inequalities in Switzerland: Which "hidden" mechanisms ? Italian Journal of Sociology of Education, 7(2), 70-98.

Goodnow, J. J. (2004). Going beyond culture and development. Human Development, 47, 117-121.

Gretler, A., Gurny, R., Perret-Clermont, A.-N., \& Poglia, E. (1989). Etre Migrant. Approches des questions socioculturelles et linguistiques relatives aux enfants migrants en Suisse (2e, original 1981 ed.). Peter Lang.

Grimshaw, T., \& Sears, C. (2008). 'Where am I from?' 'Where do I belong?': The negotiation and maintenance of identity by international school students. Journal of Research in International Education, 7(3), 259-278. https://doi.org/10.1177/1475240908096483.

Grossen, M. (2010). Interaction analysis and psychology: A dialogical perspective. Integrative Psychological and Behavioral Science, 44(1), 1-22. https://doi.org/10.1007/s12124-009-9108-9.

Grossen, M., \& Muller Mirza, N. (2020). Talking about cultural diversity at school: Dialogical tensions and obstacles to secondarisation. European Journal of Psychology of Education, 35(2), 243-264. https://doi.org/ 10.1007/s10212-019-00442-8.

Grossen, M., Zittoun, T., \& Ros, J. (2012). Boundary crossing events and potential appropriation space in philosophy, literature and general knowledge. In E. Hjörne, G. van der Aalsvoort, \& G. de Abreu (Eds.), Learning, social interaction and diversity - exploring school practices (pp. 15-33). Sense Publishers.

Gutiérrez, K. D. (2008). Developing a Sociocritical Literacy in the Third Space. Reading Research Quarterly, 43(2), 148-164. https://doi.org/10.2307/20068336.

Gutiérrez, K. D., Baquedano-López, P., \& Tejeda, C. (1999). Rethinking diversity: Hybridity and hybrid language practices in the third space. Mind, Culture, and Activity, 6(4), 286-303. https://doi.org/10.1080/ 10749039909524733.

Gyger Gaspoz, D. (2013). Une jeunesse au souffle de la mobilité internationale répétée. Etude exploratoire et descriptive de l'impact de l'itinérance géographique sur le développement à l'adolescence. [Doctoral Thesis]. University of Neuchâtel.

Hacohen, C. (2012). "The norm is a flux of change": Teachers' experiences in international schools. Educational Psychology in Practice, 28(2), 113-126. https://doi.org/10.1080/02667363.2011.646092

Hayden, M., \& Thompson, J. (1995). International Schools and International Education: A relationship reviewed. Oxford Review of Education, 21(3), 327-345. https://doi.org/10.1080/0305498950210306.

Hedegaard, M. (2003). Cultural minority children's learning within culturally-sensitive classroom teaching. Pedagogy, Culture and Society, 11(1), 133-151.

Hutmacher, W. (1995). Enfants d'ouvriers ou enfants d'immigrés? In E. Poglia, A.-N. Perret-Clermont, \& P. Dasen (Eds.), Pluralité culturelle et éducation en Suisse. Être migrant II (pp. 107-136). Peter Lang.

Kronig, W. (2003). Eléments d'interprétation du faible taux de réussite scolaire des enfants immigrés dans le degré primaire. In CDIP (Ed.), Le parcours scolaire et de formation des élèves immigrés à "faibles" performances scolaires. CONVEGNO 2002: Rapport final (Conférence suisse des directeurs cantonaux de l'instruction publique (CDIP), pp. 24-33).

Kronig, W., Haeberlin, U., \& Eckart, M. (2000). Immigrantenkinder und schulische Selektion. Pädagogische Visionen, theoretische Erklärungen und empirische Untersuchungen zur Wirkung integrierender und separierender Schulformen in den Grundschuljahren. Haupt.

Langinier, H., \& Gyger Gaspoz, D. (2015). Expatriates' and teenagers' nomadic identities: An intersectional analysis. Equality, Diversity and Inclusion: An International Journal, 34(4), 308-324 http://search.proquest. com/psycarticles/docview/1681477343/abstract/30E00149BB114932PQ/3.

Levitan, D. (2018). The art of living in transitoriness: The international mobility of professionals and their families [PhD Dissertation]. Université de Neuchâtel. 
Levitan, D. (2019). The art of living in transitoriness: Strategies of families in repeated geographical mobility. Integrative Psychological and Behavioral Science, 53(2), 258-282. https://doi.org/10.1007/s12124-018-9448-4.

Ley, D. (2004). Transnational spaces and everyday lives. Transactions of the Institute of British Geographers, 29(2), 151-164. https://doi.org/10.1111/j.0020-2754.2004.00122.x.

Manatschal, A., \& Stadelmann-Steffen, I. (2013). Cantonal variations of integration policy and their impact on immigrant educational inequality. Comparative European Politics, 11(5), 671-695.

Marková, I. (2003). Dialogicality and social representations: The dynamics of mind. Cambridge: Cambridge University Press.

Marsico, G., Komatsu, K., \& Iannaccone, A. (2013). Crossing boundaries: Intercontextual dynamics between family and school. Information Age Publishing.

Mehmeti, T., \& Perret-Clermont, A. N. (2016). Seeking Success of Migrant Students through Designed Tasks: A Case Study with Albanian Students in Switzerland. In A. Surian (Ed.), Open Spaces for Interactions and Learning Diversities (pp. 137-150). Rotterdam: Sense Publishers.

Mehmeti, T., \& Zittoun, T. (2019). Using symbolic resources to overcome institutional barriers: A case study of an albanian-speaking young woman in Switzerland. In P. Hviid \& M. Märtsin (Eds.), Culture in Education and Education in Culture: Tensioned Dialogues and Creative Constructions (pp. 177-198). Berlin: Springer. https://doi.org/10.1007/978-3-030-28412-1_11.

Meyer, T. (2015). Inégalités dans le(s) système(s) d'éducation suisse(s): Facteurs systémiques et devenir individuel. In G. Felouzis \& G. Goastellec (Eds.), Les inégalités scolaire en Suisse (pp. 161-177). Peter Lang.

Moll, L. C., Amanti, C., Neff, D., \& Gonzalez, N. (1992). Funds of knowledge for teaching: Using a qualitative approach to connect homes and classrooms. Theory Into Practice, 31(2), 132-141. https://doi.org/10.1080/ 00405849209543534.

Müller, R. (2001). Die Situation der ausländischen Jugendlichen auf der Sekundarstufe II in der Schweizer Schule Integration oder Benachteiligung ? Schweizerische Gesellschaft Für Bildungsforschung, 23(2), 265-298.

Muller Mirza, N. M. (2016). Emotions, development and materiality at school: A cultural-historical approach. Integrative Psychological and Behavioral Science, 1-21. https://doi.org/10.1007/s12124-016-9348-4.

Nedelcu, M. (2012). Migrants' New Transnational Habitus: Rethinking Migration Through a Cosmopolitan Lens in the Digital Age. Journal of Ethnic and Migration Studies, 38(9), 1339-1356. https://doi.org/10.1080/ 1369183X.2012.698203.

Nicolet, M., Rastoldo, F., Badoux, B., Vaud, Centre de recherches pédagogiques, Genève (canton), \& Centre de recherches psychopédagogiques. (1997). Regard de l'élève migrant sur son parcours scolaire et personnel. In LEP : Centre vaudois de recherches pédagogiques ; Centre de recherches psychopédagogiques du Cycle d'orientation de Genève.

Office Fédéral de la Statistique. (2008). La population étrangère en Suisse. Edition 2008. Neuchatel: Office Fédéral de la statistique.

Othenin-Girard, C. (1995). Bilinguisme et acquisition du langage chez l'enfant de travailleur migrant. In E. Poglia, A.-N. Perret-Clermont, \& P. Dasen (Eds.), Pluralité culturelle et éducation en Suisse. Être migrant II (pp. 221-231). Peter Lang.

Pearce, R. (2013). International Education and Schools: Moving Beyond the First 40 Years. A\&C Black.

Perregaux, C. (1996). Surreprésentation des élèves étrangers dans l'enseignement spécialisé. Pédagogie spécialisée, 3(/96), 6.

Perregaux, C. (2009). Elèves issus de familles migrantes: Interroger les catégories, revisister les évidences. In G. Chappelle \& M. Crahay (Eds.), Réussir à apprendre (pp. 155-167). Presses Universitaires de France.

Perret-Clermont, A.-N. (2004). The thinking spaces of the young. In A.-N. Perret-Clermont, C. Pontecorvo, L. Resnick, T. Zittoun, \& B. Burge (Eds.), Joining Society: Social Interactions and Learning in Adolescence and Youth (pp. 3-10). Cambridge University Press.

Perret-Clermont, A.-N. (2015). The architecture of social relationships and thinking spaces for growth. In C. Psaltis, A. Gillespie, \& A.-N. Perret-Clermont (Eds.), Social Relations in Human and Societal Development (pp. 51-70). New York: Palgrave.

Piguet, E. (2005). L'immigration en Suisse depuis 1948 - Une analyse des flux migratoires. Zurich, Switzerland: Seismo.

Piguet, E. (2007). L'immigration en Suisse: 50 Ans d'entrouverture (2nd ed.). Presses polytechniques et universitaires romandes.

Piguet, E. (2012). Soixante ans d'entrouverture. Terra Cognita, 21, 12-14 http://www.terra-cognita.ch/21/piguet.pdf.

Piguet, É. (2018). La « crise migratoire » de 2015/16 en Europe: Interprétation géohistorique. Refuge: Canada's Journal on Refugees, 34(2), 3-15 https://refuge.journals.yorku.ca/index.php/refuge/article/view/40498.

Piguet, E. (2019). Asile et réfugiés. In Repenser la protection. Savoir Suisse: Presses polytechniques et universitaires romandes. 
Poglia, E. (1989). Questions posées. Etre enfant de migrants en Suisse. In A. Gretler, R. Gurny, A.-N. PerretClermont, \& E. Poglia (Eds.), Etre Migrant. Approches des questions socioculturelles et linguistiques relatives aux enfants migrants en Suisse (2e, original 1981 ed., pp. 5-38). Peter Lang.

Py, B. (1995). Aspects linguistiques des migrations. In E. Poglia, A.-N. Perret-Clermont, \& P. Dasen (Eds.), Pluralité culturelle et éducation en Suisse. Etre migrant II (pp. 167-171). Peter Lang.

Rochex, J.-Y. (1998, 2018). Le sens de l'expérience scolaire. Presses universitaires de France. In A. Rosa \& J. Valsiner (Eds.), The Cambridge handbook of sociocultural psychology (2nd ed.). Cambridge University Press. https://doi.org/10.1017/9781316662229.

Rosenberg, S., Lischer, R., Kronig, W., Nicolet, M., Bürli, A., Schmid, P., \& Bühlmann, R. B. (2003). Le parcours scolaire et de formation des élèves immigrés à «faibles» performances scolaires. (CONVEGNO 2002: Rapport final). Conférence suisse des directeurs cantonaux de l'instruction publique (CDIP).

Sanchez-Mazas, M., Changkakoti, N., \& Mottet, G. (2018). Scolarisation des enfants de demandeurs d'asile: Nouvelles pratiques, nouveaux dispositifs, nouveaux « métiers » sous le signe de l'incertitude. Raisons éducatives, 22, 223-248. https://doi.org/10.3917/raised.022.0223.

Sanchez-Mazas, M., Mottet, G., \& Changkakoti, N. (2020). From War to Peace, from Chaos to School: A Study Among Asylum-Seeking Families in Switzerland | European Journal of Social Science Education and Research. European Journal of Social Science Education and Research, 7(1), 6-14 http://journals.euser. org/index.php/ejser/article/view/4595.

Schertenleib, G. A. (2014). Les représentations d'enseignants primaires sur l'hétérogénéité de leurs élèves. Revue Suisse de Pédagogie Spécialisée, 3, 27-33.

Schnell, P., \& Fibbi, R. (2016). Unequal Pathways. School-to-Work Trajectories for Children of Turkish and Western-Balkan Origin in Switzerland and Austria. Swiss Journal of Sociology, 42(2), 266-290. https://oi. org/10.1515/sjs-2016-0012.

Schuh, S. (1989). Luciano et l'antre des éléphants. Sous la pression de l'école: L'enfant migrant coincé entre deux mondes. In A. Gretler, R. Gurny, A.-N. Perret-Clermont, \& E. Poglia (Eds.), Etre Migrant. Approches des questions socioculturelles et linguistiques relatives aux enfants migrants en Suisse (2e, original 1981 ed., pp. 235-250). Peter Lang.

Shapiro, S., \& Ehtesham-Cating, M. (2019). From comfort zone to challenge: Toward a dynamic model of English Language teacher advocacy in secondary education. TESOL Journal, 10(4), e488. https://doi.org/10. 1002/tesj.488.

Steiner, I., \& Wanner, P. (2019a). Migrants and Expats: The Swiss Migration and Mobility Nexus. Springer International Publishing https://www.springer.com/gp/book/9783030056704.

Steiner, I., \& Wanner, P. (Eds.). (2019b). Migrants and Expats: The Swiss Migration and Mobility Nexus. Springer International Publishing. //www.springer.com/gp/book/9783030056704

UN - Department of Economic and Social Affair. (2019). The number of international migrants reaches 272 million, continuing an upward trend in all world regions, says UN. In UN DESA | United Nations Department of Economic and Social Affairs https://www.un.org/development/desa/en/news/population/ international-migrant-stock-2019.html.

Valsiner, J. (2007). Culture in minds and societies: Foundations of cultural psychology. Sage.

Valsiner, J. (2014). An invitation to cultural psychology. Sage.

Volksschulamt (2016a). Deutschunterricht als Zweitsprache Zusammenstellung. Kanton Solothurn. https:// soschule.ch/wp-content/uploads/2016/05/201602-Deutschunterricht-als-Zweitsprache.pdf

Volksschulamt (2016b). Flucht und Migration : Situierung August 2016. https://www.sprachenunterricht.ch/ sites/default/files/Flucht\%20und\%20Migration\%20Situierung\%20August\%202016.pdf

Walker, D. (2014). A pedagogy of powerful communication: Youth radio and radio arts in the multilingual classroom (1 edition). Peter Lang.

Warren, B., Ballenger, C., Ogonowski, M., Rosebery, A. S., \& Hudicourt-Barnes, J. (2001). Rethinking Diversity in Learning Science: The Logic of Everyday Sense-Making. Journal of research in science teaching, 38(5), 529-552.

Wicht, B., \& Bühlmann, R. B. (2003). Avant-propos. In S. Rosenberg, R. Lischer, W. Kronig, M. Nicolet, A. Bürli, P. Schmid, \& R. B. Bühlmann (Eds.), Le parcours scolaire et de formation des élèves immigrés à «faibles» performances scolaires (p. 5). Conférence suisse des directeurs cantonaux de l'instruction publique (CDIP).

Zittoun, T. (2004). Preapprenticeship as a transitional space. In A.-N. Perret-Clermont, C. Pontecorvo, L. Resnick, T. Zittoun, \& B. Burge (Eds.), Joining Society: Social Interaction and Learning in Adolescence and Youth (pp. 153-176). Cambridge University Press.

Zittoun, T. (2006). Insertions. A quinze ans, entre échecs et apprentissage. [Insertions. Being fifteen, from failure to apprenticeship]. Peter Lang.

Zittoun, T. (2014). Trusting for learning. In P. Linell \& I. Marková (Eds.), Trust and language (pp. 125-151). Information Age Publishers. 
Zittoun, T. (2016). Living creatively, in and through institutions. Europe's Journal of Psychology, 12(1), 1-11. https://doi.org/10.5964/ejop.v12i1.1133.

Zittoun, T. (2017a). Symbolic resources and sense-making in learning and instruction. European Journal of Psychology of Education, 32(1), 1-20. https://doi.org/10.1007/s10212-016-0310-0.

Zittoun, T. (2017b). Modalities of generalization through single case studies. Integrative Psychological and Behavioral Science, 51(2), 171-194. https://doi.org/10.1007/s12124-016-9367-1.

Zittoun, T., \& Grossen, M. (2012). Cultural elements as means of constructing the continuity of the self across various spheres of experience. In M. César \& B. Ligorio (Eds.), The interplays between dialogical learning and dialogical self (pp. 99-126). Information Age Publishing.

Zittoun, T., \& Levitan, D. (2019). A sociocultural psychology of repeated mobility: Dialogical challenges / Una psicología sociocultural de la movilidad repetida: desafíos dialógicos. Estudios de Psicología, 40(1), 79106. https://doi.org/10.1080/02109395.2018.1560025.

Zittoun, T., \& Perret-Clermont, A.-N. (2009). Four social psychological lenses for developmental psychology. European Journal for Psychology of Education, 24(2), 387-403.

Zittoun, T., Valsiner, J., Vedeler, D., Salgado, J., Gonçalves, M., \& Ferring, D. (2013). Human development in the lifecourse. Melodies of living: Cambridge University Press.

Publisher's note Springer Nature remains neutral with regard to jurisdictional claims in published maps and institutional affiliations.

Laure Kloetzer

Learning and development in formal and informal settings. Schools and mobility, performing arts as pedagogical tools in higher education. Transformations of teaching-learning in highly technological workplaces.

Research methodologies in education and psychology and social transformation

Sara Clarke-Habibi

Education, conflict and peacebuilding. Migration and education. Teacher training, identity and practice. Youth, civic education, advocacy and peacebuilding. Diversity, intergroup relations, and intercultural education.

Teuta Mehmeti

Thinking and argumentative processes in school tasks resolution. Educational settings favoring an anti-deficit approach.

Tania Zittoun

Development in the lifecourse. Aging, imagination and the arts, and mobility.

\title{
Affiliations
}

\section{Laure Kloetzer ${ }^{1} \cdot$ Sara Clarke-Habibi ${ }^{1} \cdot$ Teuta Mehmeti $^{1} \cdot$ Tania Zittoun $^{1}$}

\section{Laure Kloetzer}

laure.kloetzer@unine.ch

\author{
Sara Clarke-Habibi \\ sara.clarke-habibi@unine.ch \\ Teuta Mehmeti \\ teuta.mehmeti@unine.ch
}


Tania Zittoun

tania.zittoun@unine.ch

Institute of Psychology and Education, University of Neuchâtel, Espace Tilo-Frey 1, 2000 Neuchâtel, Switzerland 